\title{
Assessment of Teacher's Professional Competence, Teacher's Teaching Experience on the Implementation of Environmental Education Curriculum in Cross River State, Nigeria
}

\author{
Ambe, Benjamin Ayua \\ Agbor, Cassidy Eta
}

Department of Curriculum and Teaching, University of Calabar, Calabar, Nigeria Email address: benjamin.a.ambe@unical.edu.ng.

\section{Doi:10.5901/jesr.2014.v4n6p521}

\section{Abstract}

The purpose of this study was to examine some teacher variables and the implementation of the environmental education curriculum in Cross River State, Nigeria. Two research hypotheses were formulated to guide the study: Teachers' professional competence has no significant relationship with the implementation of the environmental education curriculum in Cross River State. Teachers' teaching experience has no significant relationship with the implementation of the environmental education curriculum in Cross River State. Literature review was carried out according to the variables under study. The ex post- facto research design was adopted for the study. A sample of four hundred and eighty (480) teachers was selected for the study. The selection was done through the stratified and simple random sampling techniques. The questionnaire was the main instrument used for data collection. The reliability estimate of the instrument was established through the split- half reliability method and its associated spearman- brown prophecy formula. The Pearson product movement correlation and one- way analysis of variance (ANOVA), were the statistical tools employed to test the hypotheses at 0.05 level of significance. The result of the analysis revealed that. Teachers' professional competence has a significant relationship with environmental education curriculum implementation but Teachers' teaching experience does not significantly influence the implementation of the environment education curriculum in Cross River State.

Keywords: Teachers' professional competence, Teachers' teaching experience, Implementation, Environmental education curriculum

\section{Introduction}

The National policy on Education (2004), advocates for the production of a people who can apply knowledge in the improvement and solutions of environmental problems for the use and convenience of human kind. In line with the National policy on education, the Nigerian National Environmental Education core curriculum was developed in 1996 by the Nigerian Educational Research and Development Council (NERDC); with support from United Nations Development programme (UNDP). This curriculum came up seven years after the formulation of the National Policy Environment in 1989 which was revised in 1999.

A major strategy for the implementation of the policy goals is through effective dissemination of relevant environmental information for attitudinal change. The policy identifies environmental education as a dynamic instrument for change which in both formal and non-formal settings will lead to the inculcation of environment ethics, values and skills to accept the responsibility of protecting the environment and ensuring rational utilization of natural resources. The policy stipulates that government shall promote comprehensive curriculum reviews that integrate environment and development concepts in the educational systems.

The curriculum implies all desirable and positive experiences available to a learner while undergoing an instructional, training or an educational programme within a given context. The curriculum has six stages. The stages are: the curriculum determination stage, the curriculum design stage, the curriculum development stage, the curriculum implementation stage, this is what happens in the classroom, seminar or in a workshop; when the curriculum is made to have direct impact on the target audience. At this stage, the teacher is a consultant, a motivator, a supervisor, a trainer, a student of students and a rescuer on the curriculum The other stages are curriculum evaluation stage, and the curriculum innovation stage.

The Baguada conference of 1985 formed the platform upon which the Nigeria Environmental Education Curriculum sprang-up. The National Conservation Education strategy, which was discussed at the 1988 Yankari Conference, was adopted in 1990 by the National Council on Education as part of the national Policy on education. 
Environmental education concepts were incorporated into the curriculum of citizenship education. This process of incorporation was completed at a workshop in 1992 sponsored by Nigeria Educational Research and Development Council and United Nations Education, Scientific and Cultural Organization (UNESCO). The process of the development of the environmental education curriculum engaged several non-governmental Organizations such as Nigeria Conservation Foundation, World wide fund for Nature (WWF), several government agencies such as Federal Ministry of Education, National Council on Education, individual teachers of secondary Schools, Universities and College of Education Lecturers among others, in series of brainstorming workshops, symposia and seminars.

Nigeria is broken into three regions; the Southern, the middle belt, and the Sahelian Regions respectively for the purpose of this curriculum. This regionalization is reflected in the designing of the environmental education curriculum. Such practice is to allow the implementers the opportunity to include their cultural and local experiences into the curriculum content. The environmental education curriculum is broken down into five stages to meet the various groups of learners at their various levels namely: non-formal learners, tertiary institutions, Senior and Junior secondary schools and primary schools.

As an ingredient for public awareness and action on the environment, the National Environmental Education Curriculum focuses on the elements of the environment and their interactions and interdependence. Thus, it is an educational intervention 'about' the environment 'in' the environment and 'for' the environment. The environmental education curriculum at all levels is structured into four areas namely: ecological foundation, human environment development, environmental change, and sustainable development to allow for easy infusion of environmental education objectives into existing school subjects.

The activities carried out by a teacher in a school system include: setting objectives, planning instructional strategies, selecting and arranging instructional materials, setting and marking examination questions, motivating students, attempting to infuse discipline and control in the classroom among other functions. To aid the curriculum implementation process, the teachers' responsibilities listed in the 1999 Environmental education curriculum document include incorporating environmental education objectives and strategies into existing subject programmes as appropriate, developing students' values and skills through value classification and analysis, group dynamics and decision making, encouraging students participation by involving them in firsthand experiences.

\subsection{Statement of the problem:}

The curriculum implementers (teachers) seem to be facing challenges that have made the implementation of the environmental education curriculum impossible in the school system. A critical look at primary and secondary Schools textbooks reveals that environmental education concepts are clearly not written about, how then is it integrated into other subjects? One is concerned about the forces that have worked against this laudable programme of the Federal Government. Could the problem be that of teachers who are seen as the most crucial link between the target audience (learners) and the environmental education curriculum? Teachers can make or mar the curriculum implementation process. Is it that teachers do not understand the environmental education curriculum, are there teacher factors that affect or is the environmental educational education curriculum not included in the curriculum of teacher education?

\subsection{Objectives of the Study}

This study seeks to:

i. Ascertain the relationship between teachers' professional competence and the implementation of the environmental education curriculum in Cross River State.

ii. Examine the influence of teachers' teaching experience on the implementation of the environmental education curriculum in Cross River State.

\subsection{Hypotheses of the study}

The following hypotheses have been formulated for this study:

i. Teachers' professional competence has no significant relationship with the implementation of environmental education curriculum in Cross River State.

ii. Teachers' teaching experience has no significant relationship with the implementation of the environmental of the environmental education curriculum in Cross River State. 


\section{Literature Review}

\subsection{Teachers' professional competence and curriculum implementation}

Distinguishing professional competence from professional qualification, Alade (2006) stated that professional competence has to do with 'how to teach', whereas, professional qualification refer to the teachers level of education and knowledge in the subject he teaches. Lee (2000) and Givens (2000) are among the authors who wrote extensively about professional competence and the relationship with teaching effectiveness. Awokoya (1999) and Elliot, Krantochill, Cook and Travex (2000) wrote of professional competence in terms of methodology or instructional techniques of the teachers, classroom management, and effective communication. Stressing the need and importance of professional competences, Awokoya (1999) asserted that before going into the profession, the teacher must have a period of internship like a doctor, a lawyer, or an Accountant during which he is groomed in the techniques of teaching under an experienced teacher. From the above, it is deducible that professional competence has to do with the teachers' practical experience in the act of preparing, planning and presenting lessons in the classrooms.

\subsubsection{Lesson preparation}

A teachers' perception of the implementation of the curriculum to a large extent depends on his prowess in preparing for his lesson. Lesson preparation is the process of gathering materials or facts by the teacher to build up a lesson he intends to deliver, preparation and planning for a lesson always go together. Bascia (1999) emphasized the importance of preparing ones lesson before presenting. The lesson that is not well prepared usually contains incomplete subject matter, incorrect facts and lacks the necessary details and appropriate illustrations. The presentation becomes disorderly, haphazard and uncoordinated. Offorma (2004) listed some vital issues in preparing a lesson to include; preliminary items such as the topic of the lesson, the class to be taught, the duration and date, intermediary information such as entry behavior and lesson objectives, and the body of the lesson plan set out in well-defined columns, indicating sequentially.

(i) The content

(ii) The teachers' activities

(iii) Students' activities

(iv) Cognitive strategies and

(v) Instructional materials and media P. 35.

Jacobson, Eggen, Kauchuk and Dulaney (2001) observed that to be successful and assist students in the mastery of the materials under study, the teacher must prepare thoroughly. They stated that this will help him think carefully about what will happen in the classroom, know reasons for carrying out certain activities and select variety of methods of teaching the pupil.

\subsubsection{Lesson Planning}

Offorma (2004) defined lesson planning as a systematic ordering of instructional events planned to happen within a period of instruction. Inyang-Abia (2001) explained that effective lesson planning is the starting point for effective curriculum implementation. He states that apart from specifying the preambles, (subject, lesson, class, duration etc), the lesson plan should specify the behavioural objectives to reflect various levels and domains in clear measurable and observable terms. Adesina, Fagbongbe and Talabi (2005) outlined many benefits for a teacher who plans his lessons to include: orderly presentation of facts, easy remembrance and reproduction of facts, careful consideration of learners' age, sex, interest etc, selection of appropriate teaching methods and adequate time management.

A teacher, with no professional competence, may find it difficult to plan and prepare the day's lesson sequentially. Such a teacher may want to avoid teaching the unplanned lesson so as not to expose his ignorance before his students. Also, teachers with no professional qualification may find planning and preparation of the lesson difficult. Teachers', who therefore lack Environmental Education professional competence and qualification, may perceive the implementation of the environmental education curriculum negatively as compared to those with such qualification and competence. 


\subsubsection{Lesson presentation}

Lesson presentation refers to the actual act of teaching or instruction in the classroom. It involves the use of effective communication skills, application of effective teaching strategies and classroom management techniques; effective implementation is dependent on effective presentation of lessons in the classroom or classroom management (Ukeje 2000). Lee (2000) submitted that good teaching or presentation depends on the quality of teacher's prowess, quality of language used in the classroom and quality of questioning techniques.

Essien (1999) surveyed the effects of teacher characteristics on the implementation of the revised physics curriculum in Akwa Ibom State Secondary Schools using a 21 item structured questionnaire. He hypothesized that teaching effectiveness among physics teachers does not differ on the basis of professional competence. His hypothesis was treated using the chi-square analysis, the data obtained from the 260 teachers sampled showed the following results; out of the 145 teachers identified as highly effective in terms of professional competence, 82 were highly effective while 63 were not. As for the 115 categorized as low in terms of professional competence, 72 were highly effective in teaching while 43 were low in terms of teaching effectiveness. A chi-square analysis of the above frequencies gave a calculated t-value of 0.82 as against the critical t-value of 3.84 . The result implied that teaching effectiveness among physics teachers does not significantly differ on the basis of professional competence. This however, contradicts other studies.

\subsection{Teachers' teaching experience and curriculum implementation}

House (2003), Morin (2003) and Brown (2004) maintained a neutral position concerning teachers' experience and curriculum implementation. Empirical research works like those of Lee (2000), and Feldman (2006) indicated no support for the topic; but those of Brown, Cervero, and Johnson-Bailey (2002), Swin, Bergida, Maruyana and Myers (1999) as well as Sergioranni (2002), and Hudson (2006), favoured teaching experience as an important factor in curriculum implementation. In many agencies where labour is employed, a major criterion for employment is experience or the number of years a person had worked in similar positions(s) prior to applying for the new position.

Is experience essential for teachers in the curriculum implementation process? Fullan (2003) answered this question in the following words: "Teacher education is a matter of lifelong learning, starting before one enters teaching, pre-service, and continuing throughout ones career" (p. 114). Researchers have observed that experienced teachers operate from a deeper and more sophisticated knowledge base. Fullan (2003) identified seven types of knowledge that is acquired by experienced teachers to include: content knowledge (knowledge the genetics of the subject area), pedagogical content knowledge (knowledge of how to make the subject interesting and understandable), general pedagogical knowledge (knowledge strategies for managing students' behaviour); Curriculum knowledge (knowledge of the content of school, state and national curriculum), knowledge of learners and their characteristics (who the students are and how to get them to learn), knowledge of educational context (knowledge how school and classroom work can be related to community and employment demands), knowledge of educational aims, values, and their philosophical and historical backgrounds (knowing school size and class size, facilities location, grade or ownership of schools).

West (2000) researched on teacher factors affecting the implementation of business education curriculum in schools in Port Harcourt Municipal Area of Rivers State. The researcher hypothesized that Business Education teachers years of teaching experiences will not significantly affect their teaching skills. The hypothesis was tested using the Pearson product moment correlation coefficient technique; the data for the study was derived from a structured questionnaire. The test results indicated a strong positive relationship $(r=0.78)$ between teachers' years of teaching experience and teacher ability to effectively implement the curriculum for learners' change in behavior and increased score in test questions. The researcher went on to conclude that a teachers' years of teaching experience culminates to improved teaching skills and proper techniques in the curriculum implementation process.

\section{Methodology}

\subsection{Research design}

The ex-post-facto research design was used for the study. This is because it is a systematic empirical inquiry in which the researcher does not have direct control of the independent variables because their manifestations had already occurred or because they are inherently not maniputable. Inferences about relationships among variables are made 
without direct intervention of independent variables.

\subsection{Sample and sampling technique:}

The stratified random sampling technique was used for this study. This is because the population is homogeneous and contains definite subsets. Firstly, to select the sample schools, all the 250 schools in the study area were stratified into four (4) based on the educational zones of Calabar (73 schools), Ugep (65 schools), Ikom (51 schools), and Ogoja (61 schools). So, all the schools in Calabar zone formed stratum 1, those in Ugep stratum 2, Ikom stratum 3 and Ogoja stratum 4. The sample was further stratified into male and female.

A hat- and - draw simple random technique was adopted in each zone to select the three used for the study giving a total of twelve (12) schools. From each of the twelve schools, forty respondents were selected using the hat- and draw simple random sampling technique. The forty (40) respondents in each school were again stratified into male and female. Thereafter, each group of respondents (male and female) was subjected to simple random sampling technique to get the desired number of males and females.

The sample for this study consists of four hundred and eighty (480) teachers. That is $13.21 \%$ of the total number of three thousand, six hundred and thirty four $(3,634)$ teachers spread across the 4 educational zones of the State.

\subsection{Instrumentation}

The instrument used for this study was a questionnaire constructed by the researcher titled "Teachers Perception of Environmental Education Questionnaire (TPEEQ)". The questionnaire was made up of three (3) sections; A, B and C. there are thirty seven (37) items in all. Section A- seeks demographic data from the respondents such as: gender: (male and female), academic qualification, area of study and teaching experience. Section B seeks teachers' perception of the implementation of the environmental education curriculum; and section C looks at teachers' professional competence. The respondents were required to rate the responses as follows:

$$
\text { Strongly Agree - SA; } \quad \text { Agree - A; } \quad \text { Disagree - D; } \quad \text { Strongly Disagree - SD }
$$

For section $\mathrm{B}$; while in section $\mathrm{C}$, the respondents stated whether the statements in the questionnaire are true or false.

To test for validity, the instrument was first examined by the supervisor and later face validated by two experts in measurement and evaluation. The initial pool was made up of 60 items. Some items were merged and a few others rewritten for inclusion in the instrument. The items were finally cut down to 37.

To determine the reliability of the instrument, a trial testing was carried out using the split-half reliability method. By this method, the researcher administered the instrument once on thirty (30) respondents. These respondents were never used for the study again. But at the time of scoring, two sets of scores were derived (odd and even). The scores derived from the two sets were correlated using Pearson product Moment correlation analysis and then corrected with the spearman Brown prophecy formula. The reliability estimate values of 0.89 and 0.86 were high enough to justify the use of the instrument for the study.

\subsection{Method of data collection}

The questionnaire was administered to the respondents during school session. The researcher visited all the selected schools after having sent a letter of introduction from the head of department, to administer the questionnaire to the selected respondents. The researcher and his assistant stayed back to collect the completed questionnaires from the teachers.

\subsection{Method of data analysis}

In this section, each of the hypotheses was re-stated in the null form. The variables as well as the statistical techniques employed to test the hypotheses were identified and presented on tables. All hypotheses were subjected to testing at 0.05 level of significance. 


\subsubsection{Hypothesis 1}

Teachers' professional competence has no significant relationship with the implementation of environmental education curriculum in Cross River State.

Table 1: Pearson product moment correlation analysis of the relationship between teachers' professional competence and the implementation of the environmental education curriculum $(n=478)$.

\begin{tabular}{lccr}
\hline Variables & $\overline{\mathrm{X}}$ & $\mathrm{SD}$ & r-value \\
\hline $\begin{array}{l}\text { Teachers' professional } \\
\begin{array}{l}\text { Competence } \\
\text { Implementation of EE }\end{array}\end{array}$ & 26.78 & 3.16 & \\
$\begin{array}{l}\text { Curriculum } \\
\text { * significant at } 0.05 \text { level, critical } \mathrm{r}=0.088, \mathrm{df}=478\end{array}$ & $0.96^{*}$ \\
\hline
\end{tabular}

The result in table 1 indicates that the calculated r-value of 0.96 was higher than the critical r-value of 0.088 at 0.05 level of significance with 478 degrees of freedom. With this result, the null hypothesis was rejected.

This result therefore implies that, teachers' professional competence has a significant relationship with implementation of the environmental education curriculum in Cross River State.

\subsubsection{Hypothesis 2}

There is no significant influence of teachers' teaching experience and the implementation of the environmental education curriculum.

The independent variable in this study was teachers' teaching experience (in years) which is categorized into four $(0-5,6-10,11-20$, and 21 and above); while the dependent variable was the implementation of the EE curriculum. The one- way analysis of variance (ANOVA) was adopted to test this hypothesis. The result of the analysis was presented on table 2.

Table 2: Summary of one-way analysis variance (ANOVA) of the influence of teachers' teaching experience on the implementation of the environmental education curriculum in Cross River State Schools $(n=480)$.

\begin{tabular}{|c|c|c|c|c|c|}
\hline $\begin{array}{l}\text { Teachers' teaching } \\
\text { Experience }\end{array}$ & $\mathrm{n}$ & & $\overline{\mathrm{X}}$ & & $\mathrm{SD}$ \\
\hline $0-5$ years & 87 & & 40.63 & & 2.99 \\
\hline $6-10$ years & 101 & & 27.04 & & 3.18 \\
\hline $11-20$ years & 189 & & 26.77 & & 2.78 \\
\hline $21-35$ & 103 & & 26.82 & & 3.63 \\
\hline Total & 480 & & 28.09 & & 3.98 \\
\hline Source of variation & SS & $\mathrm{df}$ & MS & & f-value \\
\hline Between group & -60559.53 & 3 & -20186.5 & & \\
\hline Within group & 4058492.76 & 476 & 8526.25 & -2.37 & \\
\hline Total & 3997933.23 & 479 & & & \\
\hline
\end{tabular}

The result in table 2 indicates that the calculated f-value of -2.37 was less than the critical f-value of 2.62 at 0.05 level of significance with 3 and 478 degrees of freedom. With this result, the null hypothesis was retained. This result therefore means that teachers' years of teaching experience does not significantly influence the implementation of the environmental education curriculum in Cross River State.

\section{Discussion of findings}

The discussion of the findings that emerged from the result of the analysis is presented in this section. The presentation was done according to the hypotheses directing the study.

Analysis of hypothesis one sought to examine Teachers' professional competence and the implementation of the environmental education curriculum in Cross River State. The findings of this hypothesis is in line with the views of Awokoya (1999) who asserted that before going into the profession, the teacher must have a period of internship like a 
doctor, lawyer, or an accountant during which he is groomed in the techniques of teaching under an experienced teacher. This professional competence helps the teacher to build self confidence in him which will also affect the way he perceives the subject matter he is handling

Analysis of hypothesis two looked at Teachers' teaching experience and implementation of environmental education curriculum in Cross River State.

The result of this hypothesis showed that, teachers' years of teaching experience do not significantly influence the implementation of the environmental education curriculum in Cross River State Schools. This finding is in line with the view of Ashton (2000) who noted that mere experience is not enough in the classroom situation. The author pointed out that effective teaching fails when a teacher fails to learn no matter how long he must have taught. In other words, a teacher might hold professional qualifications but if he fails to learn what he teaches, and if he fails to abreast himself of current developments in his chosen field of study. Then, experience serves no useful purpose.

\section{Conclusion}

Based on the result of the study, the following conclusions were reached: Professionally competent teachers perceive environmental education curriculum implementation better ,because what is needed for proper teaching is the skills in lesson preparation, planning and presentation, skills in teacher-pupil relation, classroom management, their quality teaching. And these are skills a professionally competent teacher should hold.

Teachers' years of teaching experience has no influence on the implementation of the environmental education curriculum in Cross River State schools. This result went this way because ability to implement the environmental education curriculum is not a function of how long an individual has taught. A good teacher not minding how long he has taught will deliver his lesson effectively.

\section{Recommendations}

Based on the study, the following recommendations were made:

Pre-employment aptitude test should be administered to would be teachers to check for elements of professional competence before they are finally employed and periodic training for teachers should be included in the schools calendar.

Government agencies responsible for monitoring curricula implementation should make sure the environmental education curriculum is implemented in secondary schools by teachers by carrying out spontaneous checks on teachers' lesson notes, syllabus and observing them as they teach in the classroom.

\section{References}

Alade, I.S.O. (2006). Promoting effective teaching-learning process in the primary school system. Journal of the Lagos state college of primary Eduaction, 1(1\&2), 111-116.

Ashton, P.T. (2000)Theme issue on Pedagogical content knowledge. Journal of Teacher Education. 41 (3), 2.

Awokoya, S.O.(1999).Teacher education. In S.O. Awokoya (Ed.).perspective of quantities and quality in Nigerian education: A synthetic report of the Baguada seminar. Lagos: Nigeria Educational Research Council,64-81.

Bascia, N. (1999).Teacher unions and educational reform. In A Hargreaves, A., Liberman., M.Fullan, D. Hopkins (Eds.), international handbook of educational change.Dordrecht:Kluwer,895-915.

Brown, A.L. (2004). The advancement of Learning Educational Research, 23(8), 4-12.

Brown, A.H. Cervero, R.M.\& Johnson-Bailey (2000).Making the invincible visible: Race, gender and teaching in adult education. Adult Education Quarterly, 50 (4),278-288.

Elliot, S.N., Kratochill,T.R., Cook J. L. \&Travex J. F. (2000). Educational psychology: effective teaching, effective learning. Boston: McGraw-Hill.

Essien,(1999). The effects of teacher characteristics on the implementation of the revised physics curriculum in Akwa Ibom State Secondary. unpublished M.ED thesis. University of Uyo, Nigeria.

Federal Republic of Nigeria (2004). The national policy on education (4th Ed.). Lagos: NERDC Press.

Feldman, K.A.(2006). The Perceived instructional effectiveness of College teaching as related to their personality and attitudinal characteristics. A review and Synthesis. Research in Higher Education. 2(4) 139-213.

Fullan, M. (2003).The meaning of educational change: A quarter of a century of learning. In A. Hargreaves., A. Libraman., M. Fullan., and D. Hopkins (Eds), International handbook on educational change. Dordretchi: Kluwer, 214-228.

Givens, N.(2000). Curriculum Materials as a vehicle for innovation: A case of the Nuffield design and technology project Research in science Education Technology Education, 18 (1), 71-84. 
House, E. (2003). The perspectives on school reform. Ibadan: University Press.

Hudson, L. (2006). Item level analysis of sex differences in Mathematics achievement test performances, New York: Unpublished Doctoral Thesis. Cornal University, Itlaca.

Inyang-Abia, M. E. (2001) Curriculum dynamics and professionalism in teaching. Calabar: MIFAM Services.

Jacobson, D. Eggen,P., Kauchuk, D.\& Dulaney,C.(2001). Methods for teaching. Columbus: Charles Merrill.

Lee, J.C. (2000). Teacher receptivity to curriculum change in the Implementation stage: the case of environmental education in Hong Kong. In Journal of Curriculum Studies. 32 (21), 95-115.

Morin, G. (2003). Does Sex Matter? Gender related belief of male and Female School Mathematics teacher. Stanford University press.

Offorma, G.C. (2004). Curriculum implementation and instruction. Ibadan: University press.

Sergioranni,T. (2002). Leadership for the Schoolhouse. San Francisco: Jossey-Bass

West I. M. (2000). Teacher factors affecting the implementation of business education curriculum in Port Harcourt Municipal area Unpublished PhD thesis, University of Port Harcourt, Nigeria. 
ISSN 2239-978X

ISSN 2240-0524
Journal of Educational and Social Research MCSER Publishing, Rome-Italy
Vol. 4 No. 6 September 2014 